\title{
Podobieństwa terminologii
} i form literackich manuskryptów z Qumran i pism Nowego Testamentu

Manuskrypty qumrańskie, odkryte w 1947 roku w jaskiniach nad Morzem Martwym, zostały szeroko udostępnione naukowcom z całego świata dopiero w 1993 roku. Od tego czasu pogłębiła się znacząco wiedza dotycząca ich treści oraz znaczenia odkryć. Rozpoczęto szczegółowe badania, które pozwalają na ich szerszą analizę w różnych aspektach. Pojawiły się szczegółowe monografie i artykuły, ukazując ich bogatą treść i pogłębiając rozumienie czasów, w których tworzył się kanon ksiąg świętych Starego Testamentu oraz powstawały pisma Nowego Testamentu.

Podobieństwa pomiędzy pewnymi sformułowaniami i niektórymi formami literackimi pism z Qumran a pismami Nowego Testamentu wynikają przede wszystkim z podłoża kulturowego, z jakiego się wywodzą, z pewnego wspólnego świata hermeneutycznego. Istotną obserwacją badaczy jest to, że najwięcej zbieżności zachodzi pomiędzy pismami qumrańskimi a najmłodszymi księgami Nowego Testamentu².

Może to dowodzić bezpośredniego zetknięcia się tych hermeneutycznych światów po śmierci i zmartwychwstaniu Jezusa Chrystusa.

\footnotetext{
Doktorantka w Instytucie Teologii Dogmatycznej UPJPII w Krakowie.

Por. S. Mędala, Wprowadzenie do literatury międzytestamentalnej, Kraków 1994, s. 35 .
} 
Mówi o tym hipoteza o dołączeniu się dużej grupy kapłanów esseńskich z Qumran do apostołów (por. Dz 6,7). Utożsamienie z esseńczykami wynika $\mathrm{z}$ faktu istnienia w tym nurcie grupy, która - jak wskazuje treść dokumentów - w izolacji na pustyni trwała wiernie w służbie kapłańskiej, mimo odłączenia się od kultu przy świątyni jerozolimskiej. Innym ugrupowaniem, z którego pochodzić mogli wspomniani kapłani, byli saduceusze i faryzeusze. Uznaje się jednak za niemożliwe, aby ich doktrynalni członkowie przysłuchiwali się tak dużą grupą nauce apostołów i uwierzyli w Jezusa Chrystusa ${ }^{3}$. Jeszcze inną teorię zainicjował tekst $\mathrm{Dz} 2,5$, gdzie wspomniana jest grupa pobożnych ${ }^{4}$ nawróconych po przemowie apostołów w dniu Pięćdziesiątnicy. Budowanie wniosku, że pobożni byli esseńczykami, budzi wątpliwości, choć nie można tego wykluczyćs.

W niniejszym artykule zostaną przedstawione podobieństwa terminologiczne pewnych sformułowań specyficznych zestawień wyrazów oraz stosowanych metod egzegetycznych. Celem jest weryfikacja hipotezy o przyłączeniu się dużej liczby członków wspólnoty esseńskiej do chrześcijan.

\section{Podobieństwa terminologiczne}

Podobieństwa językowe występują głównie pomiędzy późniejszymi tekstami Nowego Testamentu. Dotyczy to przede wszystkim pism Janowych, zwłaszcza charakterystycznego metafizycznego i etycznego dualizmu dobra i zła oraz ontycznej opozycji światłości i ciemności. Wyrazu „światłość” apostoł używa 25 razy, natomiast słowa „ciemność" 10 razy. W tekstach qumrańskich identyczne związki opozycyjne

\footnotetext{
3 Por. O. Betz, R. Riesner, Jezus, Qumran i Watykan, Kraków 1994, s. 151; S. Jędrzejewski, U korzeni zła, Lublin 1997, s. 81.

4 Esseńczycy sami nazywali siebie gorliwymi. Określenie „esseńczycy” pochodzi od Józefa Flawiusza.

5 Por. O. Betz, R. Riesner, Jezus, Qumran i Watykan, dz. cyt., s. 153.
} 
widoczne są szczególnie w rękopisie Reguły Wojny (oznaczonego jako $1 \mathrm{QM})^{6}$, w obrazie walki synów światłości z synami ciemności ${ }^{7}$.

Takie zbieżności obecne są również $\mathrm{w}$ tekstach Pawłowych oraz w Liście do Hebrajczyków. Samo nauczanie św. Pawła staje się bardziej zrozumiałe w świetle mozaiki ugrupowań judaizmu oraz samego nurtu esseńskiego $^{8}$. Jaśniejsza staje się idea nowej Jerozolimy, rozumienie sprawiedliwości, pokuty czy nadejścia Sprawiedliwego.

W języku hebrajskim słowo Pan, Adon, pojawia się często z sufiksem zaimka dzierżawczego lub z innym dookreśleniem. W Nowym Testamencie Kyrios jest już samowystarczalne, co sugeruje pochodzenie tego słowa $\mathrm{z}$ kultury greckiej. W manuskryptach z Qumran stwierdzono jednak także istnienie Adon bez dookreślenia.

Terminy semickie pojawiające się w Nowym Testamencie, a zwłaszcza u św. Pawła, w sposób szczególny ukazują podobieństwo z wyrażeniami qumrańskimi. I tak, pojęcia: „sprawiedliwość Boża”, „uczynki prawa”, „Kościół Boży”, wspomniani już „synowie światłości”, znajdują się w rękopisach qumrańskich. Podobnie pojęcie: „wielu”, stosowane przez św. Pawła oraz samego Jezusa, można porównać z hebrajskim odpowiednikiem ha-rabbim (większość). Jest on używany przez qumrańczyków jako określenie pełnego członkostwa w ich gminie. Również termin ha-mewaqqer, który w manuskryptach jest określeniem przełożonego gminy, znajduje w Nowym Testamencie odpowiednik - jest nim greckie słowo episkopos ${ }^{9}$.

W 2 Kor 6, 14-17 pojawia się też szereg podobieństw tematycznych. Należą do nich: oddzielenie sprawiedliwych i bezbożnych, dualizm światła i ciemności, imię Beliala, troska o zachowanie czystości. Zwrot: „wierne jest słowo", występujące głównie w 1 Tm 1, 15 i 4, 9; 2 Tm 2, 11; 1 Kor 1, 9; 2 Tes 3, 3 oraz Ap 22, 6, znajduje się także w qumrańskim

\footnotetext{
6 P. Muchowski, Rękopisy znad Morza Martwego, Kraków 2000, s. 44-59.

7 Por. E. Dąbrowski, Odkrycia w Qumran nad Morzem Martwym a Nowy Testament, Poznań 1960, s. 108; M. Rosik, I. Rapoport, Wprowadzenie do literatury i egzegezy żydowskiej okresu biblijnego i rabinicznego, Wrocław 2009, s. 281.

Por. J.A. Fitzmyer, 101 pytań o Qumran, Kraków 1997, s. 142.

9 Por. M. Rosik, I. Rapoport, Wprowadzenie do literatury..., dz. cyt., s. 279.
} 
rękopisie 1Q27, $1^{10}$. Inny zwrot charakterystyczny: „to jest” występujący w Rz 9, 7-9 i 10, 6-8; Dz 2, 16 i 4, 11; Mt 3, 3 i 11, 10; J 6, 50; Hbr 7, 5 oraz 1 P 1, 24, występuje w peszerach qumrańskich dość licznie. Chrześcijanie i qumrańczycy, jakkolwiek niezależnie, jednak podobnie interpretowali przygotowanie drogi dla Boga, interpretując teksty Iz 40, 3 (zob. Mt 3, 3; Mk 1, 3; Łk 3, 4-5; J 1, 23). Z taką interpretacją spotykamy się w 1QS 8-15 ${ }^{11}$. Tekst z Księgi Habakuka (Ha 2, 4b) o sprawiedliwym, który „z wiary żyć będzie”, wyjaśniany jest zarówno w Ga 3, 11 i Rz 1, 7, jak i w 1QpHab $8^{12}$.

Bruce M. Metzger przeprowadził szczegółowe badania na temat formuł wprowadzających cytaty ze Starego Testamentu zarówno w Nowym Testamencie, jak i w Misznie, jako najwcześniejszym przykładzie pism rabinicznych. Po odkryciu tekstów qumrańskich włączył je do swoich badań. Okazało się, że w tych rękopisach znalazł o wiele więcej analogicznych zwrotów z formułami tego typu niż w Misznie. Przykładowo: gr. houtos gar gegraptai, czyli „bo tak jest napisane” (Mt 2, 5; 1 Kor 15, 45), jest dosłownym tłumaczeniem hebrajskiego ki 'ken katub (1QS 5, 15; CD 11, 18 ${ }^{13}$; 2Q25 1, 3); kathos eireken - „tak, jak to powiedziano" lub „tak, jak On powiedział” (Hbr 4, 3; 3, 7) to w j. hebr. ka'aszer 'amar (CD 7, 8. 14. 16); kathos gegraptai en biblo ton propheton, czyli ,jak napisano w księdze proroków” (Dz 7, 42), w j. hebr. brzmi ka 'aszer 'katub besefer [Moszeh] (4Q174 3, 1-3; 4QpIs $\left.{ }^{\mathrm{c}} 1,4\right)$. $\mathrm{O}$ ile Metzger odnalazł podobne relacje czasownikowe w Misznie

\footnotetext{
10 Piotr Muchowski przetłumaczył qumrańskie teksty pozabiblijne i tam można odnaleźć wskazane referencje przytoczone w niniejszej pracy. Zob. P. Muchowski, Rękopisy znad Morza Martwego, Kraków 2000.

${ }_{11}$ 1QS - Reguła Wspólnoty lub Reguła Zrzeszania - dokument licznie prezentowany wśród rękopisów qumrańskich. Dotyczy regulacji życia wspólnoty i zaliczany jest do tekstów prawnych.

12 Por. P. Muchowski, Rękopisy znad Morza Martwego, dz. cyt.; M. Rosik, I. Rapoport, Wprowadzenie do literatury..., dz. cyt., s. 279.

${ }_{13}$ CD (Cairo Damascus) - Dokument Damasceński, Kodeks Damasceński lub Reguła Całego Zgromadzenia. Po raz pierwszy odnaleziony w 1864 roku w genizie kairskiej. Początkowo nie można było ustalić, kto był autorem dokumentu. Dopiero po odkryciach qumrańskich zidentyfikowano esseńczyków jako twórców tekstu.
} 
i tekstach qumrańskich, takie jak „powiedzieć” lub „pisać”, o tyle nie znalazł ich pomiędzy Miszną a Nowym Testamentem, ani tekstami qumrańskimi i Nowym Testamentem ${ }^{14}$. Tych i podobnych paralel jest więcej. Ukazały się już prace krytyczne, ukazujące badania wyłącznie na ten temat ${ }^{15}$. Oznacza to mniej więcej tyle, że autorzy Nowego Testamentu pod względem języka znajdowali się w podobnym kręgu semantycznym i teologiczno-hermeneutycznym, co esseńczycy i inne grupy apokaliptyczne.

Henryk Muszyński zajął się kwestią rozumienia „kamienia węgielnego" w świetle odkrytych zwojów. Chciał rozstrzygnąć, co ewangelista i autorzy komentarzy qumrańskich, interpretując Izajasza (Iz 28, 16-17), mieli na myśli, przywołując metaforę „kamienia węgielnego”. Dla analizy ważne były dwa terminy hebrajskie: $j s d$ i bnh - „zakładać” oraz dwa zwroty greckie: themelion tithenai - „kłaść fundament” i kefale gonias (hebr. eben pinnah) - „kamień położony w fundamencie”, czyli kamień węgielny. Po analizie tekstów doszedł do wniosku, że określenia te są stosowane w tym samym duchu interpretacyjnym. Zarówno pierwsi chrześcijanie, jak i qumrańczycy uważali się za wspólnoty czasów eschatologicznych, założone (jsd, bnh) przez wybrańca Bożego. Założył on wspólnoty, ale właściwym budowniczym, podstawą tych wspólnot, jest sam Bóg. To On położył pod nie fundament (themelion tithenai), stał się dla nich fundamentem (1 Kor 3, 10-15; Rz 15, 20; Łk 6, 48), sama Prawda objawiona dała im początek. Dzięki analizie zwrotu kefale gonias (1QS 8, 7-8; 1QH 6, 26-27'; 1QH 7, 9) można zrozumieć, czym właściwie jest kamień węgielny. Rozpatrywano głównie dwie teorie. Pierwsza mówi o kamieniu kładzionym w narożniku fundamentu budowli, rozpoczynającym i utrzymującym całą konstrukcję. Druga, po analizie tekstów qumrańskich odrzucona przez Muszyńskiego, głosiła, że kamień węgielny to kamień zwornikowy całej budowli.

\footnotetext{
14 Por. J.A. Fitzmyer, 101 pytań o Qumran, dz. cyt., s. 119-120.

15 Zob. szerzej w J.A. Fitzmyer, 101 pytań o Qumran, dz. cyt., pytanie 73, s. 125-126.

16 1QH (Hodajot) - zbiór hymnów dziękczynnych z Qumran zaliczanych do tekstów liturgicznych i kultowych.
} 
Zwieńczała ją, a zarazem utrzymywała całą konstrukcję. Tak więc sam Bóg jest kamieniem węgielnym wspólnoty i fundamentem zbawienia ${ }^{17}$.

Podobnie wzbogaca się nasza wiedza o „budowaniu na skale”, które pojawia się w przypowieści w Mt 7, 24-27, przy zmianie imienia Szymona, syna Jony, na Piotra - Kefasa (J 1, 42). Temat ten obecny jest także w wypowiedzi Chrystusa, gdy mówi Piotrowi: „Ty jesteś opoką i na tej opoce zbuduję mój Kościół, a bramy piekielne go nie przemogą" (Łk 16,18). Z manuskryptów qumrańskich dowiadujemy się o innych konotacjach tych stwierdzeń. Budowanie na skale przywołuje wspomniane wyżej budowanie na kamieniu węgielnym. Imiona Szymona

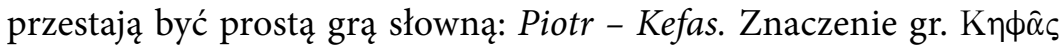
w j. aram. nabiera innego wydźwięku, po uwzględnieniu danych $\mathrm{z}$ analizy manuskryptów. W 11QtgJb 39, 28 słowo to użyte jest do opisu budowania przez orła gniazda na skale, miejsca tak wybranego, aby gniazdo było bezpieczne. Podobnie jest w 11QtgJb 39, 1, gdzie tym samym czasownikiem określono górskie urwisko koziorożców. W tym przypadku $k p^{\prime}$ odpowiada hebrajskiemu $s l^{\prime}$ (por. 1 Hen $89,29-32^{18}$ ), oznaczającemu skałę, na którą wspina się i na której pozostaje Mojżesz, przedstawiany jako baranek ${ }^{19}$.

\section{Podobieństwa egzegetyczne}

Odkrycia naświetlają pewne problemy, inne zaś stwarzają. Przykładowo dzięki nim rozwiązuje się nieścisłość, jaka nasuwała się po analizie Mt 5, 43: „Słyszeliście, że powiedziano: będziesz miłował swego

\footnotetext{
17 Zob. H. Muszyński, Chrystus - fundament i kamień węgielny Kościoła w świetle tekstów qumrańskich, Warszawa 1982.

18 Hen - Księga Henocha lub Pięcioksiąg Henocha. W Qumran odnaleziono cztery z pięciu głównych części wchodzących w skład wersji etiopskiej. Należy do grupy apokryfów, choć w Kościele koptyjskim do dziś jest uznawany za natchniony. Opisuje wizje, objawienia i sny Henocha na temat jego podróży po niebie i pałacu Boga.

19 Por. E. Puech, Manuskrypty znad Morza Martwego a Nowy Testament. Mistrzowie i nadzieje, w: Qumran. Pomiędzy Starym a Nowym Testamentem, red. H. Drawnel, A. Piwowar, Lublin 2009, s. 195.
} 
bliźniego, a nieprzyjaciela będziesz nienawidził”. Ten tekst nawiązuje do jakiegoś nakazu nienawiści nieprzyjaciół, którego próżno szukać na kartach Starego Testamentu. Pojawia się tylko pewna wzmianka w Psalmie 139, 21-22, ale jest to deklaracja psalmisty, a nie forma jurydyczna. Pomocny okazuje się w tym przypadku zapis odnaleziony w Qumran. W Regule Zrzeszenia znajdujemy bardzo wyraźny nakaz nienawiści względem wszystkich synów ciemności (1QS 1, 10-11). Możliwe, że to ich naukę krytykował Jezus w Ewangelii Mateusza (Mt 5, 38-48; por. Łk 6, 27-36) ${ }^{20}$.

W rękopisach spotykamy formuły egzorcyzmów, w oparciu o które złe duchy są wyrzucane $\mathrm{w}$ imię Boga. Są to psalmy śpiewane nad opętanym wraz z przywołaniem imienia Stwórcy. Imię wyraża jego właściciela, powoływanie się na imię Pana życia i Uzdrowiciela oznaczało posiadanie władzy Boga nad duchami. Chrystus używa tych samych formuł, ale nie powołuje się na imię Ojca, lecz własne. Tylko On może tak uczynić jako równy swemu Ojcu. Żydzi, nie rozumiejąc tego, dziwili się, gdy wyrzucał złe duchy mocą własnego autorytetu (zob. Mk 1,27). Przekazał władzę nad nimi swoim uczniom i całemu Kościołowi. Sami chrześcijanie nie odważyliby się zmienić formuły bez obawy o jej skuteczność. Uczynił to sam Chrystus, a więc słowa zapisane $\mathrm{w}$ formułach egzorcyzmów $\mathrm{z}$ Nowego Testamentu mogą należeć do rzadkich i cennych ipsissima verba Jesu (autentycznych słów Jezusa). Jaśniejsze staje się również źródło formuł stosowanych przy chrzcie, przywołujących Trójcę Świętą lub tylko samego Chrystusa ${ }^{21}$. Prezentują one płynność w sformułowaniach egzorcyzmów od czasów starotestamentalnych, poprzez okres przejściowy, ku formułom wczesnochrześcijańskim.

Powszechnie przyjmuje się, że autorzy nowotestamentowi czerpali także pojęcia i wiele myśli z kultury greckiej. Te wyrażenia, których doszukiwano się w środowisku helleńskim, możemy dostrzec również w tekstach qumrańskich. W opisie narodzin Chrystusa u św. Łukasza język, jakiego używa ewangelista, może nadal być odnoszony do kultury

20 Por. O. Betz, R. Riesner, Jezus, Qumran i Watykan, dz. cyt., s. 136.

21 Por. E. Puech, Manuskrypty znad Morza Martwego..., dz. cyt., s. 213-214. 
greckiej, ale jego korzeni należy szukać także w judaizmach ${ }^{22}$ tego czasu $^{23}$. Przykładowo idee grzesznego ciała czy predestynacji wcześniej interpretowano w duchu hellenistycznym, obecnie zaś nawiązuje się tutaj do nurtów apokaliptycznej myśli żydowskiej ${ }^{24}$.

W judaizmie często posługiwano się błogosławieństwami i przekleństwami. Sama idea błogosławieństwa od Boga, w zamian za przestrzeganie przykazań i prawe życie, jest obecna na wielu płaszczyznach. Nie ma więc nic zaskakującego w tym, że ewangeliści użyli takiej formy literackiej. Trudno było jednak porównać treść ewangelicznych błogosławieństw z innymi, ze względu na brak świadków tekstualnych $\mathrm{z}$ tego okresu. Znane są teksty rabinackie, formy ze Starego Testamentu oraz - fragmentarycznie - ze znanych tekstów apokryficznych. Obecnie posiadamy całą bibliotekę zwojów qumrańskich, pochodzących z czasów Chrystusa oraz poprzedzających je. Okazuje się, po zbadaniu 4Q525 i Mt 5, 3-12, że układ błogosławieństw jako ośmiu makaryzmów w krótkiej formie i jednym przypadku w dłuższej, jest znanym schematem, istniejącym niezależnie w tamtym czasie. Można również zauważyć, że są w treści dwie strofy (czwarta i dziewiąta) o identycznej liczbie wierszy. Oznacza to, że błogosławieństwa zapisane w Mt 5, 3-12 mają bardziej pierwotną formę względem Łk 6, 20-26, gdyż Mateusz zastosował schemat obecny także w pismach qumrańskich.

Warte zainteresowania są dwa zwroty, obecne zarówno w NT, jak i w pismach qumrańskich. Pierwszy to: „wybrani Boga” (Rz 8, 33; por. 1QS 4, 22; 8, 6; 11, 7). Drugi to: „ubodzy w duchu” (Mt 5, 3; por. 1QM 14,7). Zarówno grupa qumrańska, jak i chrześcijanie zinterpretowali siebie jako wybranych przez Boga do realizacji nowego przymierza, zapowiadanego przez Jeremiasza (31, 30-31). Jednak różnica jest znacząca. Dotyczy ona kwestii zawierania samego przymierza.

\footnotetext{
22 Przed rokiem 70 naszej ery ciężko mówić o judaizmie normatywnym ze względu na sporą mozaikę ugrupowań występujących na tamtym terenie. Elementem spajającym jest wiara w jednego Boga i Tora. Por. S. Mędala, Wprowadzenie do literatury międzytestamentalnej, dz. cyt., s. 19.

23 Por. J.A. Fitzmyer, 101 pytań o Qumran, dz. cyt., s. 101.

24 Por. M. Rosik, I. Rapoport, Wprowadzenie do literatury..., dz. cyt., s. 281.
} 
Qumrańczycy odnawiali je, składając przysięgi corocznie. Chrześcijanie trwają w przymierzu, zawartym przez Jezusa Chrystusa jednorazowo (por. Hbr 7, 27; 9, 7. 12; 10, 10). Ewangeliczne pojęcie „ubóstwa $\mathrm{w}$ duchu" zdaje się być poszerzone w stosunku do ubóstwa starotestamentalnego, tak jak to jest w 1QM 14, 7 i 1QH 6, 3. Członkowie wspólnoty wyrzekali się własności prywatnej, ale ją użytkowali. Mieli jednak udostępnić innym ze zrzeszenia, jeśliby czegoś potrzebowali ${ }^{25}$.

Ciekawym zjawiskiem jest także pojęcie Mesjasza i rozwój oczekiwań mesjańskich ${ }^{26}$. W czasach bliskich narodzinom Chrystusa napięcie, związane z oczekiwaniem na przyjście Mesjasza, w judaizmie gwałtownie narastało. Można to wywnioskować $\mathrm{z}$ intensyfikacji tej tematyki w zwiększającej się liczbie nurtów apokaliptycznych oraz ze zróżnicowania literackiego w jej prezentacji ${ }^{27}$. Różnorodność nurtów judaizmu pod koniec okresu Drugiej Świątyni ukazała zupełnie nową sytuację. Ruchy apokaliptyczne, w które wkomponuje się chrzcielna działalność Jana Chrzciciela, nawoływały do nawrócenia, gdyż nadchodziły czasy eschatologiczne. Jeśli dziwi obecnie kogoś, jak to jest możliwe, aby tylu ludzi uwierzyło w słowa Jana, to dzięki tekstom qumrańskim można to nieco objaśnić. Takie sytuacje były powszechne w Judei. Żydzi ciągle wyczekiwali znaków i proroka, który ma zapowiedzieć przyjście Mesjasza. W szczególny sposób przysłużyli się temu hasidim ${ }^{28}$ czy później esseńczycy ${ }^{29}$. Niektórzy spośród Żydów sami rozpoznali mesjasza w Jezusie albo uwierzyli, słuchając Jego nauki.

Przez wieki ukrzyżowanie uznawano za typowo rzymskie tortury. Okazuje się coś przeciwnego. Żydzi uznawali taką karę i stosowali ją w okresie hasmonejskim. Ze Zwoju Świątynnego ${ }^{30}$ dowiadujemy

\footnotetext{
25 Por. P. Muchowski, Komentarze do rękopisów..., dz. cyt., s. 51-52.

26 Por. S. Mędala, Wprowadzenie do literatury międzytestamentalnej, dz. cyt., s. 34.

27 Por. P. Muchowski, Komentarze do rękopisów..., dz. cyt., s. 70.

28 Grupa powstała prawdopodobnie za panowania Antiocha IV Epifanesa; cechowała się ortodoksją i kontestacją sposobu sprawowania kultu w świątyni i sposobu wyboru arcykapłana.

29 Por. O. Betz, R. Riesner, Jezus, Qumran i Watykan, dz. cyt., s. 148.

30 Zwój Świątynny lub Zwój Świątyni - zwój z przepisami odnoszącymi się do świątyni i kultu w niej sprawowanego. Tekst miał być podyktowany Mojżeszowi przez Boga.
} 
się, że powieszenie na drzewie - a więc praktyka żydowska - było karą hańbiącą. Oznaczało karę za zdradę wobec całego ludu Bożego ${ }^{31}$. Spekulowano, czy powieszenie na drzewie oznaczało powieszenie już martwego ciała, czy jeszcze żyjącego człowieka. Po dokładnej analizie sekwencji wyrazów oraz semantycznym rozpatrzeniu znaczenia samych wyrażeń składających się na opis kary i jej przyczyn stwierdzono, że chodzi o ukrzyżowanie żywego skazańca. Gdyby miały być to zwłoki, niepotrzebne byłoby przebijanie kończyn gwoźdźmi. W Komentarzu do Nahuma ${ }^{32}$ znajduje się opis ukrzyżowania faryzeuszów i jest tam mowa o żywych, a w Zwoju Świątynnym odnajdujemy wprost stwierdzenie o żywych ludziach wieszanych na drzewie ${ }^{33}$.

Krzysztof Pilarz, analizując problematykę pneumatologiczną w tekstach qumrańskich, wykazuje, że zwoje qumrańskie nie odbiegają $\mathrm{w}$ jej rozumieniu od znaczenia biblijnego. Zakres znaczeniowy słowa rûach, występującego w pismach pozabiblijnych 620 razy, a w Biblii hebrajskiej 387 razy (11 w pismach aram. $)^{34}$, jest dość zróżnicowany. W zależności od poszczególnych tekstów rozróżnić można znaczenia: wiatru, oddechu, ducha, zasady życia, Ducha Bożego, ducha ludzkiego. W Didache czy w Liście Barnaby jest precyzyjne rozgraniczenie dualizmu światła i ciemności. W Qumran ów dualizm wskazuje bardziej na rozwój angelologii, demonologii i twierdzeń dotyczących Szatana jako przeciwnika człowieka. W szczególności zbiór Hodajot wykazuje myślową bliskość Nowemu Testamentowi ${ }^{35}$.

Ciekawym zjawiskiem jest również rozumienie świątyni u qumrańczyków. Pojmują siebie jako świątynię Jahwe (jahad). Takie wnioski wysunął Alfred Skrzypczyk po przebadaniu tej tematyki

\footnotetext{
Prawdopodobnie chodzi o świątynię eschatologiczną. Należy on do grypy tekstów prawnych.

31 Por. O. Betz, R. Riesner, Jezus, Qumran i Watykan, dz. cyt., s. 142.

32 Komentarz Nahuma lub Peszer do Księgi Nahuma (4Q169) - jeden z lepiej zachowanych peszerów qumrańskich. Opisuje aktualne wydarzenia w Judei.

33 Por. E. Puech, Manuskrypty znad Morza Martwego..., dz. cyt., s. 218-225.

34 Por. K. Pilarz, Pneumatologia qumrańska, Toruń 2015, s. 39-41, 68-72.

35 Por. K. Pilarz, Pneumatologia qumrańska, dz. cyt., s. 119-121.
} 
w manuskryptach qumrańskich (pominął w badaniach teksty biblijne). W 39 rękopisach pojawia się toponim ${ }^{36}$ „świątynia” aż 131 razy. Okazuje się, że w pismach parabiblijnych, dokumentarnych i kalendarzowych, toponim nie występuje ani $\mathrm{razu}^{37}$. Natomiast pojawia się w dokumentach prawnych aż 95 razy. Kolejno w tekstach liturgicznych i kultowych 18 razy oraz w tekstach egzegetycznych 7 razy. Tylko raz pojawia się w tekstach dydaktycznych ${ }^{38}$. Wyniki są jednak zawyżone, ponieważ autor wliczył również teksty będące kolejnymi kopiami i każdy potraktował unikatowo.

Skrzypczyk zauważył, że w manuskryptach qumrańskich można wyróżnić cztery typy rozumienia świątyni: historyczny (świątynia jerozolimska, jako świątynia w konkretnym czasie historycznym); eschatologiczny (powiązany z historycznym; świątynia eschatologiczna ma być realną świątynią w czasie eschatologicznym); duchowy (inaczej ludzki; to wspólnota ludzi urzeczywistnia miejsce przebywania Boga); niebiański (świątynia realna, umiejscowiona poza czasem, w raju). Typ świątyni eschatycznej miał rozwiązać problem odłączenia od kultu w Jerozolimie. Jednak nie oznacza to, że qumrańczycy zakwestionowali Syjon jako miejsce wybrane przez Boga. Oczekiwali nadejścia czasów ostatecznych, gdy kult zostanie oczyszczony. Uważali, że zbezczeszczona świątynia "przestała reprezentować objawienie i prawdę Bożą"39, więc funkcje te przeszły na zrzeszenie. Były one realizowane w postaci przestrzegania Prawa i w modlitwie. Wspólnotę zaś stanowią wybrańcy Boga, ludzie Nowego Przymierza. Są świątynią, która nie zostanie zburzona ani zbezczeszczona.

\footnotetext{
36 Toponim - autor używa tego sformułowania na określenie hebrajskich słów występujących w tekstach qumrańskich oznaczających świątynię Pana.

37 Podział tekstów na kategorie zgadza się z tym, który nadał Piotr Muchowski w Komentarzach do rękopisów znad Morza Martwego, Kraków 2000.

38 Por. A. Skrzypczyk, Idea świątyni w pismach qumrańskich, Opole 2006, s. 106-109.

39 A. Skrzypczyk Idea świątyni..., dz. cyt., s. 165.
} 


\section{Podobieństwa hermeneutyczne}

Pośród tekstów qumrańskich natrafiono na specyficzny rodzaj literacki, nazwany peszerem ${ }^{40}$. Nowy Testament zdaje się także używać takiej formy literackiej (i jednocześnie metody egzegetycznej). Mielibyśmy więc do czynienia z kolejnym argumentem, wskazującym na koneksje obu środowisk hermeneutycznych. Tekstami typu peszerowego może być cykl przypowieści w Mk 12, 1n i 12, 35-37 czy w Mt 22, 23-33. Przypominają one peszery tematyczne z Qumran, w niektórych elementach różnią się jednak od nich. Czytelnik lub słuchacz sam ma uczynić analizę i komentarz do tego, co usłyszał. Sam Jezus tworzy swoistą wykładnię, posługując się formą peszeru. Nie odwołuje się do żadnego autorytetu, aby potwierdzić własną wykładnię Pisma, gdyż sam jest autorytatywnym peszerystą. Należałoby mówić tutaj raczej o formie quasi peszeru, ledwie zdradzającego ślady typowego peszeru qumrańskiego. Przykładem jest fragment z Łk 4, 16-22, którego podstawą był Iz 61, 1-2. Istnieje również wiele różnic pomiędzy stosowaną formą qumrańską a nowotestamentalną. Teologiczne wnioski dla słuchacza czy czytającego dany tekst są różne.

Peszer qumrański miał za zadanie uaktualnienie Pisma i wytłumaczenie jego obecnego znaczenia dla identyfikacji i tożsamości grupy. Chrystus ukazuje ostateczną interpretację Prawa i spełnienie się proroctw w Jego osobie ${ }^{41}$. Można wskazać również inne teksty, potencjalnie zawierające elementy peszerowe. Będą to Rz 16, 25; Kol 1, 26; Ef $3,1-11^{42}$.

\footnotetext{
${ }^{40} \mathrm{~W}$ publikacjach polskich tematykę peszeru podejmuje S. Jędrzejewski, Biblia i judaizm, dz. cyt., s. 55-56; zob. też S. Jędrzejewski, Peszer jako metoda egzegetyczna, „Seminare” 24 (2007), s. 111-126; S. Jędrzejewski, Peszer w 2 Kor 6, 13b-18, w: Przekonywat ich o Chrystusie. Pawet - apostoł i wojownik Chrystusa, red. R. Pindel, S. Jędrzejewski, Kraków 2008, s. 39-61 (Hermeneutica et Judaica, 2); M. Rosik, I. Rapoport, Wprowadzenie do literatury..., dz. cyt., s. 284.

${ }^{41}$ Por. S. Jędrzejewski, Biblia a judaizm, dz. cyt., s. 67-70.

42 Por. M. Rosik, I. Rapoport, Wprowadzenie do literatury..., dz. cyt., s. 284.
} 
W 4Q174, klasycznym peszerze tematycznym, składającym się z różnych cytatów ze Starego Testamentu znajdujemy odniesienie do Mesjasza. We wstępie pojawia się fragment z $2 \operatorname{Sm~7,14~„Ja~będę~Mu~ojcem,~}$ a on będzie Mi synem”. W tekście oryginalnym odnosi się on do króla Izraela, który zasiądzie na tronie i w ten sposób zostanie synem Boga. W wersji qumrańskiej autor zinterpretował te słowa jako mesjańskie. „Odrośl” z linii króla Dawida zasiądzie na Syjonie „w ostatnich dniach”. Mesjasz wykazuje już cechy eschatologiczne, podobnie ukazany jest w tzw. Apokalipsie Aramejskiej (4Q246). Tekst ten wykazuje cechy wspólne $\mathrm{z}$ fragmentem $\mathrm{z}$ Łk 13, $35^{43}$.

\section{Podsumowanie}

Celem artykułu było poparcie tezy o rozpoznaniu, przez sporą część esseńczyków, Jezusa jako wyczekiwanego Mesjasza i dołączenie do chrześcijan. Podobieństwa terminologiczne nie są wystarczającym materiałem do weryfikacji tej tezy, ale stanowią kolejny argument popierający. Wiele sformułowań w tekstach qumrańskich wykazuje podobieństwa do pism nowotestamentalnych, lecz nie mają identycznego znaczenia. Pojawia się pewien rozwój myśli teologicznej, której nie znajdujemy u innych ugrupowań ówczesnych judaizmów. Trzeba jednak zauważyć, że nie mamy dostępu do tekstów faryzejskich czy saducejskich. Ich założenia znamy głównie z dyskusji z Jezusem, jakie prowokowali ich przedstawiciele.

Podsumowując, wykazane $\mathrm{w}$ artykule podobieństwa terminologiczne mogą wskazywać na dołączenie esseńczyków do chrześcijan lub ukazywać jedynie wspólne podłoże kulturowe. Esseńczycy byli wierni Prawu i poddali ewolucji jego interpretację poprzez odsunięcie się od kultu świątynnego oraz odizolowanie od cesarstwa. Również ich rozumienie siebie, własnego zrzeszenia czy misji jest

\footnotetext{
43 Por. H. Shanks, Tajemnica i znaczenie zwojów znad Morza Martwego, Warszawa 2002, s. 83.
} 
bliższe chrześcijańskiej wizji Kościoła. W momencie pojawienia się chrześcijaństwa esseńczycy zdają się w nim „rozpływać”44.

\section{Bibliografia}

Betz O., Riesner R., Jezus, Qumran i Watykan, Kraków 1994.

Dąbrowski E., Odkrycia w Qumran nad Morzem Martwym a Nowy Testament, Poznań 1960.

Fitzmyer J.A., 101 pytań o Qumran, Kraków 1997.

Jelonek T., Wprowadzenie do Nowego Testamentu, Kraków 2008.

Jędrzejewski S., Biblia i judaizm, Kraków 2007.

Jędrzejewski S., Peszer jako metoda egzegetyczna, „Seminare” 24 (2007), s. 111-126.

Jędrzejewski S., Peszer w 2 Kor 6, 13b-18, w: Przekonywat ich o Chrystusie. Pawet - apostoł $i$ wojownik Chrystusa, red. R. Pindel, S. Jędrzejewski, Kraków 2008, s. 39-61 (Hermeneutica et Judaica, 2).

Jędrzejewski S., U korzeni zła, Lublin 1997.

Mędala S., Aktualny stań badań problematyki qumrańskiej, w: Rękopisyz Qumran nad Morzem Martwym, red. W. Tyloch, Warszawa 2001, s. 9-78.

Mędala S., Wprowadzenie do literatury międzytestamentalnej, Kraków 1994. Muchowski P., Komentarze do rękopisów znad Morza Martwego, Kraków 2000. Muszyński H., Chrystus - fundament i kamień wegielny Kościoła w świetle tekstów qumrańskich, Warszawa 1982.

Pilarz K., Pneumatologia qumrańska, Toruń 2015.

Puech E., Manuskrypty znad Morza Martwego a Nowy Testament. Nowy Mojżesz, czyli o kilku praktykach Prawa, w: Qumran. Pomiędzy Starym a Nowym Testamentem, red. H. Drawnel, A. Piwowar, Lublin 2009.

Rosik M., Rapoport I., Wprowadzenie do literatury i egzegezy żydowskiej okresu biblijnego i rabinicznego, Wrocław 2009.

Shanks H., Tajemnica i znaczenie zwojów znad Morza Martwego, Warszawa 2002. Skrzypczyk A., Idea świątyni w pismach qumrańskich, Opole 2006.

44 T. Jelonek, Wprowadzenie do Nowego Testamentu, Kraków 2008, s. 321. 
Stegeman H., Esseńczycy z Qumran, Jan Chrzciciel i Jezus, Kraków-Mogilany 2002.

\section{Streszczenie}

Podobieństwa, jakie zachodzą pomiędzy essenizmem i chrześcijaństwem, u swoich podstaw mają pochodzenie ze wspólnego źródła, z judaizmu. Zbieżności oraz dystynkcje pozwalają z chrześcijańskiego punktu widzenia docenić esseńczyków za wierność przymierzu i ewolucję ich interpretacji świętych tekstów Izraela. $\mathrm{W}$ ich autopercepcji, pojmowaniu zrzeszenia i jego misji można dostrzec cechy bliskie chrześcijańskiej wizji Kościoła i jego doktrynie. Z pojawieniem się chrześcijaństwa ruch esseńczyków zanika. Zbieżności $\mathrm{w}$ terminologii, w używanych formach literackich i w interpretacji mogą stanowić pewne poparcie hipotezy o dołączeniu się esseńczyków do tworzącego się chrześcijaństwa.

Słowa kluczowe Qumran, zwoje znad Morza Martwego, Nowy Testament

\section{Summary}

\section{Similarities of the terminology and literary forms in Qumran manuscripts and in the New Testament writings}

The article is intended to support the thesis that a significant number of Essenes joined christianity. To this end, similarities of terminology, wording and specific statement of words have been collected in this work with a special stress on the two pericopes of the Acts of the Apostles. Essene priests might have influenced the editing process of John's and Paul's writings or even the Letter to the Hebrews. The similarities might be noticed in the dualities good evil, or the path of light - the path of darkness. The wordings of this two groups of texts concerns the appearance of the Pesher components, characteristic phrases, the evolution of the concept of the Messiah or the interpretation of the foundation stone from the Book of Isaiah.

Keywords Qumran, the Dead Sea Scrolls, New Testament 
A. Uniwersytet Papieski

Ifét Jana Pawła II

o. W Krakowie 